\title{
Human Resources and Islamic Microfinance Sustainability: An Empirical Study of Baitul Maal wat Tamwil in Indonesia
}

\author{
Qosdan Dawami ${ }^{1 *}$, Dzuljastri Abdul Razak ${ }^{2}$, Hamdino Hamdan ${ }^{3}$ \\ 1,2,3 Kulliyah of Economics and Management Sciences, International Islamic University, Selangor, Malaysia
}

\section{Keywords}

Islamic Microfinance

Human Resources

Baitul Maal Wat Tamwil

Sustainability And Indonesia

Received: 19 March 2021

Accepted: 07 May 2021

\begin{abstract}
.
Purpose: The main purpose of this study is to determine empirically the relationship between human resource adequacy and the sustainability of BMT in Indonesia.

Methodology: This study used a triangulation design as research method. The total number of 285 questionnaires were distributed manually to BMT staffs and analyzed using SPSS. In addition, this study also conducted semi-structured interviews with some managers of BMT.

Findings: The study findings exhibited that the relationship between human resource adequacy the sustainability of BMTs was significance and positive relationship.

Originality: This study revealed the impact of human resources on the sustainability of BMT, which to the authors' knowledge has not been conducted empirically.

Research Implications: This study recommends managers of BMT to strengthen human resources management through conducting some training programs in order to improve BMT sustainability.
\end{abstract}

KAUJIE Classification: P6, T7

JEL Classification: A19, C39, C51

\section{INTRODUCTION}

\section{Background of Study}

Islamic microfinance institutions (IMFIs) have been considered a fast-growing industry globally in the last three decades. The incredible accomplishment was derived from the significant role of IMFIs to poverty alleviation and social welfare enhancement through providing affordable Islamic financial access for the Muslim microentrepreneurs and poor. Bank of Khartoum (2016) further explained that the annual growth rate of Islamic microfinance approximately $20 \%$ globally in these few years.

Moreover, Islamic microfinance is also considered a panacea for poverty alleviation with

\footnotetext{
${ }^{*}$ Corresponding author: Qosdan Dawami

${ }^{\dagger}$ Email: qosdan.dawami@live.iium.edu.my; ORCID: https://orcid.org/0000-0003-3339-2875
} 
equity finance that attracts attention not only the academicians and practitioners, but also enchants the policymakers in worldwide. For instance, Islamic Development Bank (IDB) has a big plan for the goal of alleviating global poverty by establishing an International Islamic microfinance institution (IMFI) in collaboration with local banks (Abbas \& Shirazi, 2015).

In Indonesia, the rise of the Islamic microfinance movement was initiated by the establishment of BMT in the 1990s (Suseno, 2019). Moreover, its role has contributed significantly to social welfare improvement and been able to spread tremendously in less than three decades throughout Indonesia. Since BMT is able to offer affordable financial support and services to Muslim microentrepreneurs and poor that fits their ability and conditions, such as a collateral free loan, convenient instalment payments and provision of business management skills (Masyita \& Ahmed, 2011).

Furthermore, the ability of BMT in meeting the aspirations and high demands of the Muslim entrepreneurs and low income groups towards an access to Islamic financial inclusions has led to a tremendous development of BMT throughout Indonesia (Rusydiana \& Devi, 2013). Suseno (2019) ascertained that the BMT had documented incredible success in its infancy stage. Whereby it is documented that more than 3,000 BMTs have been established with 600,00 branches with more than 3,000 staff employed. This success trend will continue to rise along with the higher role of BMT in social welfare improvement and poverty alleviation.

However, several BMTs still face serious problems and challenges. Whereby several BMT had closed and went bankrupt caused by their inability to overcome those problems and challenges. Nasution and Ahmed (2015) asserted that the most challenging problem that destabilize the sustainability of BMT in Indonesia were inadequate capital structure and human resource. Other than that, loose supervision and guidance reduces BMT competitiveness (Rusydiana \& Devi, 2013). Moreover, Nurasyiah, Utami, Mahri, and Firmansyah (2016) further supported that an inadequate human resources of BMT is considered the main factor of the BMT competitive ability to be less power than the conventional counterpart. Then, inadequate human resource adequacy is one of the most challenging problems for BMT to be sustainable in a long time.

Hence, it is important to determine the role and impact of human resource adequacy on the sustainability of BMT. Besides, this study ascertained that there remains a big gap of empirical study on the relationship between human resource adequacy and BMT sustainability, which is this study is still very limited in the literature.

This study is organized as follows; The problem statement and the objective of the study is elaborated in this section. Next section discussed the literature review. Section three is on methodology of the study. Section four presented the analysis and discussion. Then, the last section emphasized conclusions and recommendations.

\section{LITERATURE REVIEW}

\section{Islamic Microfinance}

A tremendous growth of microfinance institutions has attracted a lot of attention and interest of both regulators and researchers around the world in the last decades, especially in 
Indonesia (Maulana et al., 2018). This attraction of microfinance institutions was influenced significantly by the conventional banking system's failure in providing the affordable financial access to the microentrepreneurs and low income groups and large losses due to loans provided by informal money lenders in the society (Dusuki, 2008).

Conceptually, microfinance is defined as micro-financing in which the institution provides several micro-products and services to microentrepreneurs and low-income groups. Moreover, Obaidullah (2008) further explained that microfinance means providing affordable financial access for unbanked people that usually has no collateral, high risk of loans, and low income economically.

In addition, Abbas et al. (2014) also emphasized that microfinance as a financial institution that provide affordable financial access to microentrepreneurs and low income people who have difficulty being able to get loans from the conventional banks at all times. Since those groups of people are considered lack of collateral, no credit history, and low business income groups, They are getting the financial services from the moneylenders, relatives and cooperatives (Alimukhamedova, 2014). Furthermore, the establishment microfinance movement was initiated by various traditional and informal civil system in assisting the needy and poor based on mutual trust for centuries (Hearth, 2018).

Microfinance institutions have been developed tremendously both in number and system. Whereby, at the operation system point of view, microfinance institutions currently are classified into two main categories, namely formal and informal microfinance institutions. Whereby informal microfinance institutions refer to those micro-finance activities at the initial stage of microfinance, such as microfinancing provided by relatives, friends, pawnbrokers, moneylenders, and traders. While formal microfinance institutions were carried out by formal institutions such as village banks, credit unions, NGOs, and some conventional banks (Obaidullah \& Khan, 2008).

However, from an Islamic perspective, numerous conventional microfinance products and services are contrary to the Islamic Sharī'ah principles and values, such as the practice of usury (ribā), gambling (maysir), and uncertainty (gharar) (Rahman et al., 2015). Hence, the establishment of Islamic microfinance institutions are considered most appropriate solution and alternative for the Muslim microentrepreneurs and low income groups in order to get affordable Islamic access of financing (Riwajanti, 2013).

Historically, the basic concept of Islamic microfinance operation is not a new concept, but its basic contracts and operations were carried out by the Last Messenger, Muhammad (PBUH). Ascarya et al. (2018) ascertained that the basic concept integration of poverty reduction and social welfare improvement of the needy and poor is a part of Islamic Shari`a teaching.

Basically, Islamic microfinance is similar to its conventional counterparts. However, Islamic microfinance has a principle difference in carrying out microfinance operation, whereby Islamic microfinance operation were based on Sharī ah principles (Riwajanti, 2013). Karim et al. (2008) also ascertained that MFIs were basically established on the amalgamation of Islamic financial institutions (IFIs) and conventional microfinance. Hence, the basic concept of IMFs and IFIs are akin from one to another, their practices were based on social spirit, 
religiosity, justice, risk sharing, and holiness of the contracts (Obaidullah \& Khan, 2008).

In addition, MFIs have documented tremendous deployment throughout the world. The CGAP further highlighted that, from more than 125 Islamic microfinance institutions and interviewed experts from 19 Muslim countries, the remarkable outreach of Islamic microfinance had been documented by reaching more than 380,000 clients globally (Karim et al., 2008).

In Indonesia, the rise of Islamic finance movement has significantly influenced the development of Islamic microfinance institution in the 1990s. This movement initiated two pilot projects of BMT emergence in Indonesia, BMT Ridho Gusti and Salman (Seibel \& Agung, 2005). Subsequently, the Micro Enterprise Incubation Centre (PINBUK) officially established the first BMT which is playing notable role in poverty alleviation and social welfare improvement (Soemitra, 2009).

BMT basically refers to an IMFI operated based on Islamic cooperative that combines IFI and MFI framework with the intention of reaching the pleasure of Allah through social outreach (Ascarya, 2017). Hence, the BMT consists of two main boards, namely Baitul Maal (house of funds) that arrange the circulation of ZISWAF from the Muzakki to the beneficiaries and Baitul Tamwil (house of financing) that generates permissible profit by providing affordable financing and support to the microentrepreneurs and low-income groups based on Islamic Sharī'ah principles.

Moreover, the BMT has been documented the tremendous development throughout Indonesia within less than one decade, whereby more than 3,000 institutions has been established (Suseno, 2019). This terrific development of BMT is supported by the cooperative law under the Ministry of Cooperatives, Small and Medium enterprise based on (Riwajanti, 2013). Adnan and Ajija (2015) also ascertained that the salient features of BMT attracted a lot of attention and sympathy from both regulators and public, namely, Sharī'ah compliance, flexibility, and profit-loss sharing.

Ideally, the main objective of BMT activities is to promote social justice and economic empowerment through providing affordable financing and support to the microentrepreneurs and low-income groups based on Islamic Sharī'ah principles (Riwajanti, 2013). Hence, the BMT is considered as the most appropriate alternative for the Muslim microentrepreneurs and low-income groups in order to promote social welfare improvement.

In practice, BMT ideally provides four main products and services, namely provision of affordable financial support and services which is free from elements forbidden by Sharī'ah principles, provision of business skill management training programs, avoiding the dependency of the microentrepreneurs and poor on illegal moneylenders, promoting social justice and public welfare (Sudarsono, 2007).

\section{Human Resource Adequacy}

An adequate human resource affects directly and indirectly organization or institution success story. Haneef et al. (2015) highlighted that three main challenges of microfinance sustainability are inadequate human resources, cost operation and interest rate issues. they also ascertained that relationship between IFIs and its staffs is a strong relationship. Whereby the 
human acts as main player of Islamic microfinance and Islamic microfinance acts as main platform.

Furthermore, as cited in (Riwajanti, 2013), Platteau and Slewertsen (2010) emphasized that the sustainability and stability of financial institution are significantly determined some main factors, namely the investment capacity, access to technology and human resource adequacy. Nurasyiah et al. (2016) also ascertained that the most determinant of BMT sustainability is human capital adequacy, whereby its adequacy is measured by several elements, such as financial literacy, skills, motivation, and experiences.

In addition, As cited in (Wahyuni, 2017), Buck et al also emphasized that the adequacy of human resources and capital inputs were considered as one important factor that determines the performance of a company or a firm. Moreover, the more appropriate labor hired strategy the more competitiveness a company has.

H1: Human Resource Adequacy has a positive impact on the sustainability of BMT in Indonesia.

\section{Conceptual Framework}

The conceptual framework of the study illustrated the hypothesis stated earlier regarding the relationship between human resource adequacy and the sustainability of BMTs in Indonesia. Hence, with refer to the above literature review, the proposed that relationship this is figured out as follows:

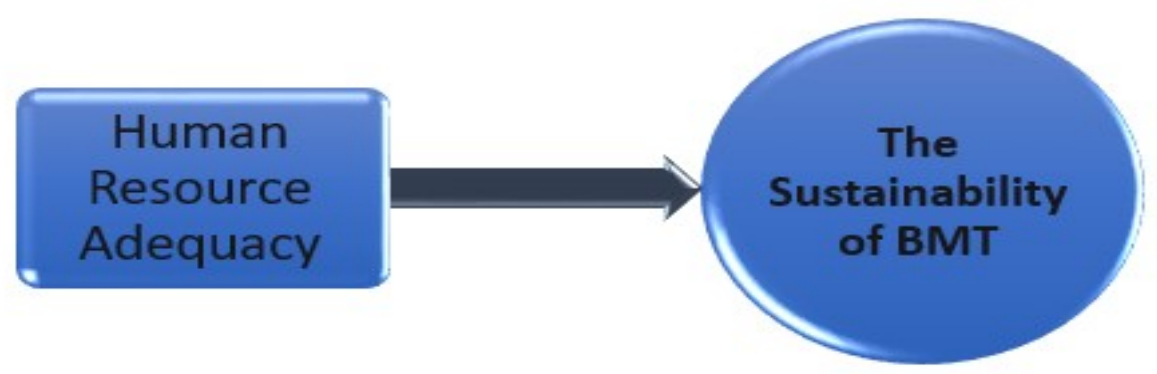

FIGURE 1. Conceptual framework of the study

\section{METHODOLOGY}

\section{Population}

The population of this study is all BMTs in the country which amounted to about 5000 units all over Indonesia. However, in consequence of Covid-19 pandemic, time and budget constraint in collecting data related to this study. This study focuses and restrict the investigation of this study on the BMTs in Wonosobo, Central Java, Indonesia. Hence, the population of this is all BMTs and its staffs in Wonosobo, which is estimated to be 8 BMTs with around 1000 BMT staffs.

In addition, three main reasons in determining Wonosobo as the city of investigation as follows: 
i. Wonosobo is a city in Central Java with the total population about 790,504 in 2019 in which its annual population growth rate is approximately 4.34\% (BPS Jawa Tengah, 2020). ii. According to 2019 data, the number of cooperatives in Wonosobo was 350 cooperatives. Whereby $40 \%$ of them or 100 cooperatives experienced instability and unhealthy performance (Sunandar, 2019).

iii. According to 2019 data, Wonosobo ranks the second poorest city in Central Java with around $16,63 \%$ of the total population were living below the poverty line (Suara Merdeka, 2020).

\section{Sample and Sampling Methods}

Accordingly, the sample of this study is about 285 staffs and 3 managers of the BMTs in Wonosobo. This study adopted Slovin's sampling method in determining the total samples required in the study. With refers to Slovin's sampling method, the minimum sample of the study is 285 respondents.

\section{Data Collection and Analysis Methods}

This study employed a triangulation design as research method. The total number of 285 questionnaires were distributed manually to BMT staffs and analyzed using SPSS. In addition, this study also conducted semi-structured interviews with some managers of BMT in Wonosobo city, Central Java.

Furthermore, demographic section of the questionnaire initiated by previous study perfromed by Haque et al. (2009). This section conducted to obtain the data regarding characteristics of the respondents, namely gender, marital status, age, qualification, job titles, length of experience, and frequency of seminar attended. Whereas the second section conducted to obtain opinion of the respondents regarding the relationship between the human resource adequacy and the sustainability of BMT.

\section{ANALYSIS AND DISCUSSION}

\section{Demographic Analysis}

This section presents the result of the first section of the questionnaire. From the total of 285 questionnaires, there are only 205 questionnaires were completed successfully. Hence, the response rate of the study was about 72 percent. The summary demographic analysis is elaborated in Table 1.

The Table 1 also shows the demographic analysis of the respondents of the study. From the total 205 respondents of the study, there are 107 respondents (52.2 percent) were male, and 98 respondents (47.8) were female. The above result further exhibited that 168 ( 82 percent) respondents were married, 30 respondents (14.6 percent) were single, and 7 respondents (3.4 percent) were widowed/widower. The most frequency of the respondents is 104 respondents are aged 31-40 years. This clearly denoted that majority of the BMT staffs are aged between 31-40 years. 
TABLE 1

Demographic Analysis Result

\begin{tabular}{llll}
\hline \hline Variables & Category & Frequency & Percentage \\
\hline Gender & Male & 107 & 52.2 \\
Marital Status & Female & 98 & 47.8 \\
& Single & 30 & 14.6 \\
& Married & 168 & 82 \\
Age & Widow/Widower & 7 & 3.4 \\
& Below 20 & 1 & 0.5 \\
& 21-30 Year & 73 & 35.6 \\
Education & 31-40 & 104 & 50.7 \\
& More than 40 & 27 & 13.2 \\
& College & 71 & 34.6 \\
Job Title & D3 & 10 & 4.9 \\
& Degree & 121 & 59 \\
& Postgraduate & 2 & 1 \\
& Cashier & 21 & 10.2 \\
& DPS & 2 & 1 \\
& Manager & 15 & 7.3 \\
& Marketing & 84 & 41 \\
Length of Working & Others & 83 & 40.5 \\
& Below 1 Year & 18 & 8.8 \\
& 1-5 Year & 53 & 25.9 \\
& 6-10 Year & 74 & 36.1 \\
& More than 10 & 60 & 29.3 \\
Frequency of Training & Less than 5 & 59 & 28.8 \\
& 5-10 times & 87 & 42.2 \\
& 10-15 times & 26 & 12.7 \\
& More than 15 & 33 & 16.1 \\
\hline \hline
\end{tabular}

Moreover, the largest number of the respondent qualification in this study is 104 respondents are 121 respondents (59 percent) who qualified as undergraduate. This is good for the effectiveness of BMT because the undergraduate staffs have adequate skill and comprehensive abilities to adapt the financial institution mechanism. Meanwhile, the highest frequency of respondents in this study is Marketing officer (41 percent) and followed by others (40.5 percent). Whereby Others consist of various job titles such as accounting officer, IT staffs, head of division and so on. Furthermore, at the length or working point of view, it can be concluded that all BMT staffs are having good working experience since all of them are having above year of working experience and 29.3 percent of respondents are having more than 10 years of working experience. Besides, at the seminar and training participation point of view, it also can be concluded that most of BMT staffs are having excellent frequency 
of seminar and training participation since about 71,2 percent of respondents attended the training more than 5 times.

\section{Validity and Reliability Test}

The Validity test is a test used to identify the validity of questionnaires in the data collection. This test basically was conducted using Bivariate (Pearson) Correlation analysis using SPSS version 24.0. Whereby the item of questionnaires will be considered as valid item if $\mathrm{R}$-calculated is higher than an R-table at the 5 percent significance level. On the other hand, the item of questionnaires will be considered as invalid item if R-calculated is smaller than an R-table at the 5 percent significance level. The result of validity test and analysis is shown in Table 2 and Table 3.

TABLE 2

Validity Test of Human Resource Adequacy

\begin{tabular}{lllll}
\hline \hline Variable & Question & $\begin{array}{l}\text { Correlated } \\
\text { Item/ R- } \\
\text { Calculated }\end{array}$ & Decision \\
\hline $\begin{array}{l}\text { Human } \\
\text { Resource } \\
\text { Adequacy }\end{array}$ & $\begin{array}{l}\text { Human Resources can con- } \\
\text { tribute to sustainability of } \\
\text { BMT } \\
\text { Adequate human resources can }\end{array}$ & 0.687 & \\
& $\begin{array}{l}\text { reduce the cost of operations } \\
\text { Adequate human resources can } \\
\text { reduce the moral hazard and } \\
\text { asymmetry information. }\end{array}$ & 0.835 & 0.138 & Valid \\
$\begin{array}{l}\text { Adequate human resource can } \\
\text { improve the effectiveness and } \\
\text { profitability of BMT. } \\
\text { Adequate human resource can } \\
\text { be used to set up business train- } \\
\text { ing center for the poor in my } \\
\text { community. }\end{array}$ & 0.785 & Valid \\
\end{tabular}

The Table 2 depicted the validity test of Human Resource Adequacy. The results exhibited that R-calculated of item 1 to 5 are $0.687,0.802,0.835,0.784,0.785$ respectively. Accordingly, it can be seen that all items of Human Resource Adequacy have the R-calculated greater than the R-table (0.138) at the 5 percent significance level. Hence, it was concluded that all items of this variable are valid and are appropriate for further statistical analysis.

The table 3 exhibited the validity test the BMT sustainability. It depicted that the Rcalculated of item 1 to 5 are $0.833,0.864,0.843,0.846,0.812$ respectively. It can be seen that all items of the BMT sustainability have the R-calculated greater than the R-table $(0.138)$ 
at the 5 percent significance level. Hence, it was indicated that all items of this variable are valid and are appropriate for further statistical analysis.

TABLE 3

Validity Test of the BMT Sustainability

\begin{tabular}{|c|c|c|c|c|}
\hline Variable & Question & $\begin{array}{l}\text { Correlated } \\
\text { Item/ R- } \\
\text { Calculated }\end{array}$ & R-Table & Decision \\
\hline \multirow{5}{*}{$\begin{array}{l}\text { The Sus- } \\
\text { tainability } \\
\text { of BMT }\end{array}$} & $\begin{array}{l}\text { BMT has financial revenue } \\
\text { growth annually. }\end{array}$ & 0.833 & 0.138 & Valid \\
\hline & $\begin{array}{l}\text { The operation of BMT has im- } \\
\text { proved the social welfare of } \\
\text { both BMT's staffs and mem- } \\
\text { bers. }\end{array}$ & 0.864 & 0.138 & Valid \\
\hline & $\begin{array}{l}\text { The revenue of BMT can meet } \\
\text { operating costs and long-term } \\
\text { cost }\end{array}$ & 0.843 & 0.138 & Valid \\
\hline & $\begin{array}{l}\text { The deposit of members is in- } \\
\text { creasing both in total deposi- } \\
\text { tors and deposit amount }\end{array}$ & 0.846 & 0.138 & Valid \\
\hline & $\begin{array}{l}\text { BMT is able to revive the sus- } \\
\text { tainability during economic cri- } \\
\text { sis }\end{array}$ & 0.812 & 0.138 & Valid \\
\hline
\end{tabular}

Moreover, the next test is a reliability test. The Reliability test is a statistical test used to measure the level of confidence and consistency of the questionnaire as a primary data collection instrument. This test applied the Cronbach's Alpha analysis in determining the the level of confidence and consistency of the questionnaire. The items of the questionnaire will be considered as Reliable if the Alpha is greater than the R-table at the 5 percent significance level. On the other hand, if the Alpha is less than the R-table at the 5 percent significance level, the items of the questionnaire will be concluded as unreliable. The result of validity test and analysis is shown in Table 4.

TABLE 4

Reliability Test Analysis

\begin{tabular}{lllll}
\hline \hline Variable & Reliability Coefficient & Alpha & R-Table & Decision \\
\hline Human Resource Adequacy & Five questions & 0.837 & 0.138 & Reliable \\
The Sustainability of BMT & Five questions & 0.895 & 0.138 & Reliable \\
\hline \hline
\end{tabular}

The table 4. showed reliability test result of the questionnaires. It exhibited that the Cronbach Alpha $(\alpha)$ of Human Resource Adequacy and the Sustainability of BMTs are 0.837 
and 0.895 respectively. It indicated that both variables have the Cronbach Alpha ( $\alpha$ ) higher than the R-table (0.138) at the 5 percent significance level. Hence, it was concluded that each variable of questionnaires is reliable and then the questionnaire can be used consistently for conducting another research.

\section{Simple Linear Regression Analysis}

The next analysis is simple linear regression analysis, this analysis used to determine relationships between Human Resource Adequacy and the Sustainability of BMTs. The summary of simple linear regression analysis is elaborated in the Table 5.

TABLE 5

Simple Linear Regression Result

\begin{tabular}{llllll}
\hline \hline & \multicolumn{2}{l}{ Unstandardized Coefficients } & \multicolumn{3}{l}{ Standardized Coefficients } \\
\hline Model 1 & $\beta$ & Std. Error & Beta & $t$ & Sig. \\
\hline Constant & 5.386 & 1.232 & & 4.372 & .000 \\
Human Resource & .747 & .059 & .665 & 12.694 & .000 \\
\hline \hline
\end{tabular}

The Table 5 above exhibited simple linear regression result. The result pointed that the coefficients of the constant and human resource adequacy are 5.386 and 0.747 respectively. Hence, it can be concluded that human resource adequacy has positive relationship with sustainability of BMT since its coefficient has positive value.

However, the above result is not the final result, but its significance needs to be verified using T-test. Whereby the above result also exhibited that the computed significance value of human resource adequacy was 0.00 . Thus, it can be concluded that human resource adequacy has a significant impact on the sustainability of BMTs since its computed significance value is less than the probability value at the 0.05 significance level.

TABLE 6

Coefficient of Determination Result

\begin{tabular}{lllll}
\hline \hline \multicolumn{5}{c}{ Model Summary } \\
\hline Model 1 & $R^{2}$ & $R^{2}$ & Adj. $R^{2}$ & $F$ \\
\hline & .665 & .443 & .440 & 2.139 \\
\hline \hline
\end{tabular}

The Table 6 exhibited the Coefficient of Determination Result. It denoted that the Coefficient of Determination of this model is 44.3 percent. It means the human resource adequacy determined the sustainability of the BMT at the 44.3 percent determination. Moreover, this study triangulated both administered questionnaires and semi-structured data as the primary data of this study. Whereby this study conducted semi-structured interviews with three main informants, namely Mr. Kurnianto, S.E as the manager of BMT Bina Surya Mandiri (M1), Mrs. Farida Erwin Haryanti as the manager of BMT Al-Hikmah (M2) and the manager of 
BMT Tamzis (M3). The semi-structured interviews were recording using mobile phone, then it was transcribed, coded and analyzed as follows:

Research Question 1: Problems and challenges of BMT. Basically, BMT still faces some unresolved problem that could disrupt its sustainability. One of the managers (M1) ascertained:

\begin{abstract}
"Almost all of the BMTs capital comes from their members' savings, it indicated that the BMTs capital is indeed inadequate as their members' savings is very limited. Therefore, all of them mostly have to deal with external sources of capital such as Islamic banks, government and so on."
\end{abstract}

It was further supported by Third manager (M3) statement:

"The feature of BMT is having flexible regulation, this is the biggest challenge for BMT, if BMT can utilize it properly, it will get a lot of benefits. On the contrary, if BMT cannot manage it properly, is caused bankruptcy and failure. BMT is like being at the bottom up, started from the absence of regulations. It is different from the banking industry, which has had a bundle of regulations since its inception. Therefore, those flexible regulations become a major challenge for the BMTs, some of BMTs misused the looseness of regulations which resulted them to have many operational problems and fall into bankruptcy."

The next problem that faced by BMT is inadequate human resources. This was illustrated that First manager (M1) said:

"The first obstacle of BMT is inadequate human resources, whereby our human resources were not recruited in a ready-to-work situation. We learn by trial and error in BMT, if we try and get wrong, we will try it again until we get it right."

The next problem is lack of understanding towards Islamic transaction contracts. Furthermore, most of BMT members are microentrepreneurs who have not proper knowledge towards Islamic economics and finance, they are also old already. Hence, if they are going to take financing products, they just want to know how much they must pay the instalments are. This is in the line with the statement of second manager (M2) as follows:

"The most challenging problems faced by BMT are giving explanations towards Islamic transaction contracts to the BMT members, especially when they will take financing products, who are mostly not highly educated, not familiar with those contracts and they just simply said: "Please... Let me know in a nutshell.... If I borrow this amount of money, how much is the instalment are...". Hence, it is difficult for BMT staffs give a comprehensive explanation towards Islamic transaction contracts." 
Human resources adequacy of BMT plays significance role in managing capital structure adequacy and good corporate governance. This was supported by the statement of First manager (M1) as follows:

"The first factor that significantly determines the sustainability of BMT is human resource adequacy. How to make our staffs as qualified human resources also important because the recruitment of BMT staffs is not specifically for financial or Islamic economics experts. On the other hand, BMT recruits diverse staffs with diverse mindsets and diverse educational background on condition that they are ready to try and learn."

\section{DISCUSSION}

Nurasyiah et al. (2016) emphasized that there is a correlation between inadequate human resource and unsustainability of BMT in Indonesia. Nasution and Ahmed (2015) also supported that inadequate human resource issue destabilizes the sustainability and outreach of BMTs.

However, there remain a gap of empirical study on the impact of human resource adequacy on the BMT sustainability in the literature. Hence, by combining the results of previous studies as the theoretical framework of this study, the results of this study can lessen the gap in providing empirical study of this field. In accordance with the simple linear regression and T-test, it can be concluded that the human resource adequacy has positive and significant impact on the sustainability of BMT. This result is consistent with the previous studies, namely Nasution and Ahmed (2015), Nurasyiah et al. (2016), Rusydiana and Devi (2013), and Zubair (2016) regarding the positive impact of the human resource adequacy on the sustainability of BMT.

Furthermore, the statement of First manager (M1) further supported that the determinant of BMT sustainability is human resource adequacy. Thus, BMT staff human resource development is the main actor behind the human resource management from the recruitment till advance training programs of BMT staffs.

Finally, the above results also ascertained that BMTs still faced several obstacles and challenges in their operation and development, namely a lack of capital, loose regulations, Inadequate human resources, and a lack of understanding towards Islamic transaction contracts.

\section{Conclusion and Recommendation}

The purpose of this study is to investigate empirically the influence of the human resource on the sustainability of BMT in Indonesia. The demographic analysis exhibited that BMTs made an important contribution to employment opportunities as there is almost equal opportunities among genders. Besides, the findings also indicated that BMTs have relatively adequate human resources qualification as more than half portion of their staffs has undergraduate qualifications.

Moreover, the overall findings of analyses revealed that human resource adequacy has 
positive and significant impact on the sustainability of BMT based on the simple linear regression and T-test. The impact of human resource adequacy on the sustainability of BMT was approximately 44.3 percent based on the coefficient of determination analysis. Hence, this study recommends the future researcher to find out other 55.7 percent determinant of the BMT sustainability.

This study further recommends BMT managers to improve their human resources knowledge and skills by conducting regular training and seminar to sharpen their skills of Islamic finance and microfinance management.

\section{REFERENCES}

Abbas, K., Abdul Razak, D., \& Saad, N. M. (2014). The perception of micro-entrepreneurs and petty traders on conventional and Islamic microfinance: A case study of Pakistan. Journal of Islamic Finance, 3(1), 38-48. doi: https://doi.org/10.12816/0031478

Abbas, K., \& Shirazi, N. (2015). The key players' perception on the role of Islamic microfinance in poverty alleviation: The case of Pakistan. Journal of Islamic Accounting and Business Research, 6(2), 244-267. doi: https://doi.org/10.1108/JIABR-06-2013-0017

Adnan, M. A., \& Ajija, S. R. (2015). The effectiveness of Baitul Maal wat Tamwil in reducing poverty. Humanomics, 31(2), 160-182. doi: https://doi.org/10.1108/h-03-2012-0003

Alimukhamedova, N. (2014). Contribution of microfinance to economic growth: Transmission channel and the ways to test it. Business and Economic Horizons, 9(4), 27-43. doi: https://doi.org/10.15208/beh.2013.20

Ascarya, A. (2017). Baitul Maal wat Tamwil (BMT): An integrated Islamic social and commercial finance institution in Indonesia. Isra-Thomson Reuters, IRTI Islamic Commercial Law Report, Kuala Lumpur, Malaysia.

Ascarya, A., Rahmawati, S., \& Tanjung, H. (2018). Design the roadmap of holistic financial inclusion for Baitul Maal wat Tamwil. Tazkia Islamic Finance and Business Review, 12(1), 1-32. doi: https://doi.org/10.30993/tifbr.v12i1.112

Bank of Khartoum. (2016). Islamic Microfinance: From a market niche to a growing industry. Global Islamic Finance Report, Bank of Khartoum, Khartoum, Sudan.

BPS Jawa Tengah. (2020). Central Java Province in figures 2020. Retrieved from https://bit.ly/3kbw6Ip

Dusuki, A. W. (2008). Banking for the poor: The role of Islamic banking in microfinance initiatives. Humanomics, 24(1), 49-66.

doi: https://doi.org/10.1108/08288660810851469

Haneef, M. A., Pramanik, A. H., Mohammed, M. O., Amin, M. F. Bin, \& Muhammad, A. D. (2015). Integration of waqf-Islamic microfinance model for poverty reduction: The case of Bangladesh. International Journal of Islamic and Middle Eastern Finance and Management Managerial Finance, 34(10), 246-270. doi: https://doi.org/10.1108/mf.2008.00934jaa.001 
Haque, A., Osman, J., \& Ismail, A. Z. H. (2009). Factor influences selection of Islamic banking: A study on Malaysian customer preferences. American Journal of Applied Sciences, 6(5), 922-928. doi: https://doi.org/10.3844/ajas.2009.922.928

Hearth, H. M. W. A. (2018). Microfinance: Theory and practice. Godage \& Brothers (Pvt) Ltd.

Karim, N., Tarazi, M., \& Reille, X. (2008). Islamic Microfinance: An emerging market niche. Retrieved from https://bit.ly/3j144Qi

Masyita, D., \& Ahmed, H. (2011). Why is growth of Islamic microfinance lower than conventional? A comparative study of the preferences and perceptions of the clients of Islamic and conventional microfinance institutions' in Indonesia. Paper presented at the 8th International Conference on Islamic Economics and Finance, Qatar Foundation, Doha, Qatar.

Maulana, H., Razak, D. A., \& Adeyemi, A. A. (2018). Factors influencing behaviour to participate in Islamic microfinance. International Journal of Islamic and Middle Eastern Finance and Management, 11(1), 109-130.

doi: https://doi.org/10.1108/IMEFM-05-2017-0134

Nasution, R. E. F., \& Ahmed, H. (2015). Outreach and profitability trade-off: Does synergy between Islamic banking and Islamic microfinance institutions matter? Indonesian Capital Market Review, 7(2), 57-73. doi: https://doi.org/10.21002/icmr.v7i2.4853

Nurasyiah, A., Utami, S. A., Mahri, A. J. W., \& Firmansyah. (2016). The challenges of human capital performance in developing Baitul Maal Wat Tamwil in Indonesia. Advances in Economics, Business and Management Research, 15, 599-604. doi: https://doi.org/10.2991/gcbme-16.2016.112

Obaidullah, M. (2008). Role of microfinance in poverty alleviation: Lessons from experiences in selected IDB member countries. The Islamic Research and Training Institute, Jeddah, Saudi Arabia.

Obaidullah, M., \& Khan, T. (2008). Islamic microfinance development: Challenges and initiatives (Policy Dialogue Paper No. 2). The Islamic Research and Training Institute, Jeddah, Saudi Arabia.

Riwajanti, N. I. (2013). Islamic microfinance in Indonesia: A comparative analysis between Islamic financial cooperative (BMT) and Sharī'ah Rural Bank (BPRS) on Experiences, challenges, prospects, and roles in developing micro-enterprises (Ph.D. dissertation). Durham University, Durham, UK.

Rusydiana, A. S., \& Devi, A. (2013). Challenges in developing Baitul Maal Wat Tamwiil (Bmt) in Indonesia using analytic network process (Anp). Business and Management Quarterly Review, 4(2), 51-62.

Seibel, H. D., \& Agung, W. D. (2005). Islamic microfinance in Indonesia (Working Paper No. 2006.2). University of Cologne, Cologne, Germany.

Soemitra, A. (2009). Bank E Lembaga Keuangan Syariah (Pertama). Kencana Prenada Media Group.

Suara Merdeka. (2020). Crawling up, Wonosobo ranks two of the poorest in central Java. Retrieved from https://bit.ly/3z6cETu 
Sudarsono, E. (2007). Indonesian cooperative management. Rineka Cipta.

Sunandar, A. (2019). 40 Percent of cooperatives in Wonosobo declared unhealthy. Retrieved from https://bit.ly/3svgzXn

Suseno, P. (2019). Baitul Maal Wat-Tamwil (BMT ): A faith and community-based microfinance. National Committee on Shari 'ah Economics and Finance. Jakarta, Indonesia.

Wahyuni, I. S. T. (2017). Determinants of the adoption of good governance: Evidences from Zakat institutions in Padang Indonesia. Share: Jurnal Ekonomi Dan Keuangan Islam, 6(2), 118-139. doi: https://doi.org/10.22373/share.v6i2.1530

Zubair, M. K. (2016). Analisis Faktor-Faktor Sustainabilitas Lembaga Keuangan Mikro Syariah. IQTISHADIA Jurnal Kajian Ekonomi Dan Bisnis Islam, 9(2), 201-226. doi: https://doi.org/10.21043/iqtishadia.v9i2.1728 